\title{
Erratum to: Children and Forced Migration
}

\author{
Marisa O. Ensor and Elźbieta M. Goździak
}

Erratum to: Children and Forced Migration

DOI 10.1007/978-3-319-40691-6

Corrections have been carried out for clarity in the present version of the book, the research content has not been affected.

The updated original online version for this book can be found at

DOI 10.1007/978-3-319-40691-6

Marisa O. Ensor

Institute for the Study of International Migration

Georgetown University

Washington, DC, USA

Elźbieta M. Goździak

Institute for the Study of International Migration

Georgetown University

Washington, DC, USA 